\title{
Performance Evaluation of Prototype Ride on Type Paddy Weeder
}

\author{
Basavaraj $^{1 *}$, A. Surendrakumar ${ }^{2}$, Vinayak $^{3}$ and P. Vivek ${ }^{4}$ \\ ${ }^{1}$ Kelappaji College of Agricultural Engineering and Technology, KAU, \\ Tavanur-679573, India \\ ${ }^{2}$ Agricultural Machinery Research Centre, AEC \& RI, TNAU, Coimbatore-03, India \\ ${ }^{3}$ College of Agricultural Engineering, UAS, Raichur-584101, Karnataka, India \\ ${ }^{4} A E C \&$ RI, TNAU, Kumulur-Tiruchirappalli-621712, India \\ *Corresponding author
}

\section{A B S T R A C T}

\section{Keywords \\ Paddy weeder, Effective field capacity, Plant damage and Weeding efficiency}

Article Info

Accepted:

26 April 2018

Available Online:

10 May 2018

\begin{abstract}
A study was conducted for performance evaluation of prototype ride on type paddy weeder in wetland field, Tamil Nadu Agricultural University, Coimbatore, India. The experimental site is geographically situated at $11^{\circ}$ North latitude and $77^{\circ}$ East longitude and at an altitude of $427 \mathrm{~m}$ above MSL.Weed is inevitable part of farming. SRI system of rice cultivation naturally weed growth is more in the fields because there is no stagnated water. So, it is very necessary to use proper weeding implements to reduce drudgery and cost of cultivation. Performance evaluation of prototype ride on type paddy weeder was done in the paddy field. In field evaluation the of developed ride on type paddy weeder the following evaluated parameters were wheel slip $15 \%$, effective field capacity $0.03004 \mathrm{hah}^{-}$ ${ }^{1}$, theoretical field capacity $0.0375 \mathrm{ha} \mathrm{h}^{-1}$, field efficiency $80.35 \%$, plant damage $3.33 \%$ and weeding efficiency $84.04 \%$ and fuel consumption of the weeder was 0.6 lit $^{-1}$.
\end{abstract}

\section{Introduction}

Rice is an important staple food for about 50 per cent of the world's population providing 66-70 per cent body calories intake to the consumers (Barah and Pandey, 2005).The world paddy production was 614.65 million tonnes covering an area of 153.51 million hectare with an average yield of 3.87 tonnes per hectare. India has the largest area under rice in the world which comprises about 44 per cent of the total area under cereals in India and its production reached to a record high of 104.32 million tonnes in 2011-12. Weed is inevitable part of farming. Ever since man started growing crops, he had come up with the problems of weed. Farmers and researchers have been putting up a combined front to tackle the menace of weeds. Weeds are serious threat to all crops. Weeds, instead of harbouring insects, compete with the crop for water, light and plant nutrients and adversely affect the microclimate around the plant. Weeding is an important but equally labour intensive agricultural unit operation. Weeding accounts for about 25 per cent of the total labour requirement during a cultivation season (Nag and Dutta, 1979). In developing 
countries it is estimated that reduction in yield due to weeds alone is 20 to 30 per cent depending on the crops, weed infestation intensity and location, which might increase up to 50 per cent if adequate crop management practices were not observed. Human energy is predominantly used in most of the rice farming operations starting from seedbed preparation to threshing. It is estimated that nearly 145 man-days are required per hectare of rice. Among these crop, care is highly labour intensive operation accounting for 24.3 per cent of total human power requirement (Fig. 1). Hand weeding is the most common method of weed control in rice but it requires high labour input. Normally two or three manual weeding is done in rice per crop.

Among various farm operations in rice cultivation i.e. growing of seedlings, transplanting of seedlings, weeding, harvesting etc are labor intensive operations and one of the major laborious and time consuming operations in rice cultivation is weeding. The yield loss ranges from 10-50\% in transplanted rice depending on the extent of weed infestation (Pathak et al., 1976).

In Transplanted paddy cultivation, Traditional seedbed-based rice cultivation consumes higher energy for weed management in India (15.3 -23.7 \%) compared to stale seedbed because traditional farmers give their higher priority to hand weeding (Chaudhary et al., 2006). It is very clear that the estimates of time and cost for hand weeding are variable and dependent on weed flora, weed intensity, cropping season, labour availability and efficiency of weeding methods.In SRI system of rice cultivation naturally weed growth is more in the fields because there is no stagnated water. So, it is very necessary to use proper weeding implements to reduce drudgery and cost of cultivation. Performance evaluation of prototype ride on type paddy weeder was done in the paddy field.

\section{Materials and Methods}

The developed prototype ride on type paddy weeder was evaluated in M-4 plot of wetland field, Tamil Nadu Agricultural University, Coimbatore, India. The experimental site is geographically situated at $11^{\circ}$ North latitude and $77^{\circ}$ East longitude and at an altitude of $427 \mathrm{~m}$ above MSL. The soil of the experimental site was sandy clay loam as per the textural classification (USDA).Weeding was done on $25^{\text {th }}$ DAS. The spacing of paddy was $25 \times 25 \mathrm{~cm}$. The field trials were carried out at a soil moisture content of $37 \%$. The size of the plot was 0.25 acre. The performance of the machine was evaluated in terms of wheel slip, weeding efficiency, plant damage, field capacity, field efficiency and fuel consumption and Specification of ride on type paddy weeder has given Table 1 .

\section{Wheel slippage}

Wheel slip for power weeder was measured by monitoring the number of revolutions of the wheel over a specified distance under load and zero load conditions. The slip was calculated by using the following formula.

$S^{\prime}=\frac{n_{1}-n_{0}}{n_{0}} \times 100$

Where,

$\mathrm{S}^{\prime}=$ wheel slip, per cent

$\mathrm{n}_{1}=$ number of revolution of wheel under load conditions for specified distance.

$\mathrm{n}_{\mathrm{o}}=$ number of revolution of wheel under no load conditions for specified distance

In most of the cases the tool has no effect of slip at different levels of forward speed but fuel consumption increases considerably. 


\section{Effective field capacity}

The weeding machine was operated in the different test fields. The area covered during the test was calculated. The effective field capacity was calculated by using following formula

Effective field

capacity $($ ha $/ \mathrm{h})=\frac{\text { Area covered }(\mathrm{ha})}{\text { Time required }(\mathrm{h})}$

\section{Theoretical field capacity}

It is always greater than actual field capacity. The theoretical field capacity was calculated by using following formula.

T.F.C. $\left(\mathrm{ha} \mathrm{h}^{-1}\right)=(3)$

Where,

T.F.C. $=$ Theoretical field capacity, ha/h. $\mathrm{W}_{\mathrm{t}}=$ Theoretical width of operation, $\mathrm{m}$. $\mathrm{S}=$ Speed of operation, $\mathrm{km} / \mathrm{h}$.

\section{Field efficiency}

The field efficiency was calculated from theoretical and effective field capacity by using following formula.

Field efficiency $(\%)=\frac{\text { E.F.C. }}{\text { T.F.C. }} \times 100$

Where,

E.F.C. $=$ Effective field capacity, ha $\mathrm{h}^{-1}$.

T.F.C. $=$ Theoretical field capacity, ha $\mathrm{h}^{-1}$.

\section{Weeding efficiency}

The developed weeder was operated in the experimental plot. Before operation of the weeder the numbers of weeds in the plot were counted. After the operation the number of weeds left in the plot was also counted. This procedure was repeated at different depth. The forward speed was maintained at constant in all the field tests. Weeding efficiency was calculated by the following expression.

$E=\frac{W_{1}-W_{2}}{W_{1}}$

Where,

$\mathrm{E}=$ weeding efficiency, $\%$

$\mathrm{W}_{1}=$ number of weeds counted before operation in square metre area

$\mathrm{W}_{2}=$ number of weeds counted after operation, in square metre area

\section{Plant damage}

The quality of work done is the measure of damage on crop during weeding operation. It is calculated using the following expression (Remesean et al., 2007).

$\mathrm{DF}=\frac{\mathrm{Q}_{2}}{\mathrm{Q}_{1}} \times 100$

Where,

DF - Damage factor, per cent

Q1 - Number of plants in $10 \mathrm{~m}$ row before weeding

Q2 - Number of plants damaged in $10 \mathrm{~m}$ row after weeding

\section{Fuel consumption}

The fuel consumption has direct effect on economics of the weeder. It was measured by Top fill method. The fuel tank was filled to full capacity before the testing at level condition. After completion of test operation, amount of fuel required to top fill again is the fuel consumption for the test duration. 
Table.1 Specification of ride on type paddy weeder

\begin{tabular}{|c|c|c|}
\hline S. No. & Particular & Specification power weeder \\
\hline 1. & Name of machine & Self-propelled ride on type paddy weeder \\
\hline 2. & Make & TNAU Coimbatore \\
\hline 3. & Model & Prototype \\
\hline 4. & Type of machine & Self-propelled \\
\hline 5. & Overall length of machine ( $\mathrm{mm})$ & 1500 \\
\hline 6. & Overall height of machine ( $\mathrm{mm}$ ) & 950 \\
\hline 7. & Overall width of machine $(\mathrm{mm})$ & 250 \\
\hline 8. & Overall weight of machine $(\mathrm{Kg})$ & 52 \\
\hline 10. & Width of blade (mm) & 15 \\
\hline 11 & No. of blades on wheel & 28 \\
\hline 12. & Diameter of weeder (mm) & 600 \\
\hline 13. & Weight of float $(\mathrm{kg})$ & 6 \\
\hline 14. & Length of float (mm) & 850 \\
\hline 15. & Width of float (mm) & 150 \\
\hline
\end{tabular}

Table.2 Field capacity and efficiency of ride on paddy weeder

\begin{tabular}{|c|c|c|c|}
\hline Observations & Area of field in $\left(\mathbf{m}^{2}\right)$ & \multicolumn{2}{|c|}{ Ride on paddy weeder } \\
\cline { 2 - 3 } & & Effective field capacity & Field efficiency (\%) \\
\hline $\mathbf{1}$ & 300 & 0.03064 & 81.73 \\
\hline $\mathbf{2}$ & 300 & 0.02998 & 79.95 \\
\hline A verage & 300 & 0.0295 & 79.39 \\
\hline
\end{tabular}

Table.3 Weeding efficiency of weeder at 22 DAS

\begin{tabular}{|c|c|c|c|}
\hline \multirow{2}{*}{ Observation } & \multicolumn{3}{|c|}{ Ride on type paddy weeder } \\
\cline { 2 - 4 } & $\begin{array}{c}\text { Number of weeds in 1 sq.m area } \\
\text { Before weeding }\end{array}$ & Weeding efficiency \% \\
\hline $\mathbf{1}$ & 123 & 21 & 82.93 \\
\hline 2 & 131 & 23 & 82.44 \\
\hline $\mathbf{3}$ & 140 & 19 & 86.43 \\
\hline $\mathbf{4}$ & 151 & 23 & 84.77 \\
\hline $\mathbf{5}$ & 132 & 26 & 80.30 \\
\hline $\mathbf{6}$ & 127 & 19 & 85.04 \\
\hline $\mathbf{7}$ & 119 & 21 & 82.35 \\
\hline $\mathbf{8}$ & 163 & 20 & 87.73 \\
\hline $\mathbf{9}$ & 134 & 21 & 84.33 \\
\hline A verage & & & $\mathbf{8 4 . 0 4}$ \\
\hline
\end{tabular}


Table.4 Plant damage by weeder at 22 DAS

\begin{tabular}{|c|}
\hline Observations \\
\\
\hline 1 \\
\hline 2 \\
\hline 3 \\
\hline 4 \\
\hline 5 \\
\hline 6 \\
\hline 7 \\
\hline 8 \\
\hline 9 \\
\hline Average
\end{tabular}

Ride on type paddy weeder

\begin{tabular}{|c|c|c|}
\hline $\begin{array}{c}\text { Number of plants in 10 m row length } \\
\text { Before weeding }\end{array}$ & $\begin{array}{c}\text { Plant } \\
\text { damage } \%\end{array}$ \\
\hline 40 & 2 & 5.0 \\
\hline 40 & 1 & 2.50 \\
\hline 40 & 1 & 2.50 \\
\hline 40 & 1 & 2.50 \\
\hline 40 & 1 & 2.50 \\
\hline 40 & 1 & 2.50 \\
\hline 40 & 2 & 5.0 \\
\hline & 1 & 2.50 \\
\hline
\end{tabular}

Table.5 Performance evaluation of prototype ride on type paddy weeder

\begin{tabular}{|c|c|c|}
\hline S. No. & Parameters & Values \\
\hline 1. & Wheel slip, \% & 15 \\
\hline 2. & Weeding efficiency, \% & $84.4 \%$ \\
\hline 3. & Plant damage, \% & 3.33 \\
\hline 4. & Field capacity, ha $\mathrm{h}^{-1}$ & 0.0306 \\
\hline 5. & Field efficiency, \% & 80.35 \\
\hline 6. & Fuel consumption, lit $\mathrm{h}^{-1}$ & 0.6 \\
\hline
\end{tabular}

Fig.1 Labour requirement in rice farming

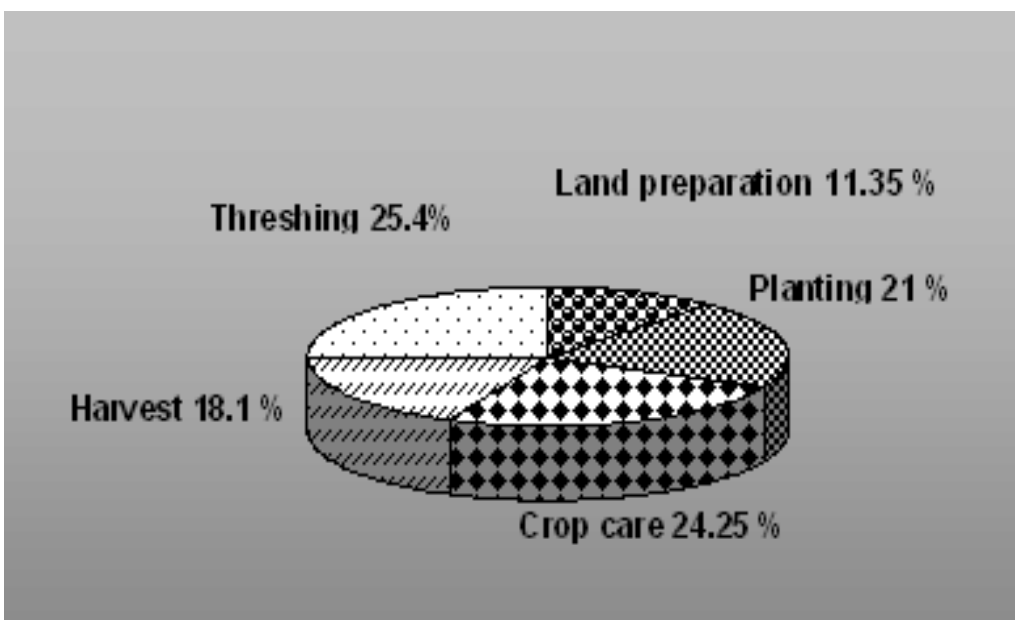


Fig.2 Field view of ride on type paddy weeder

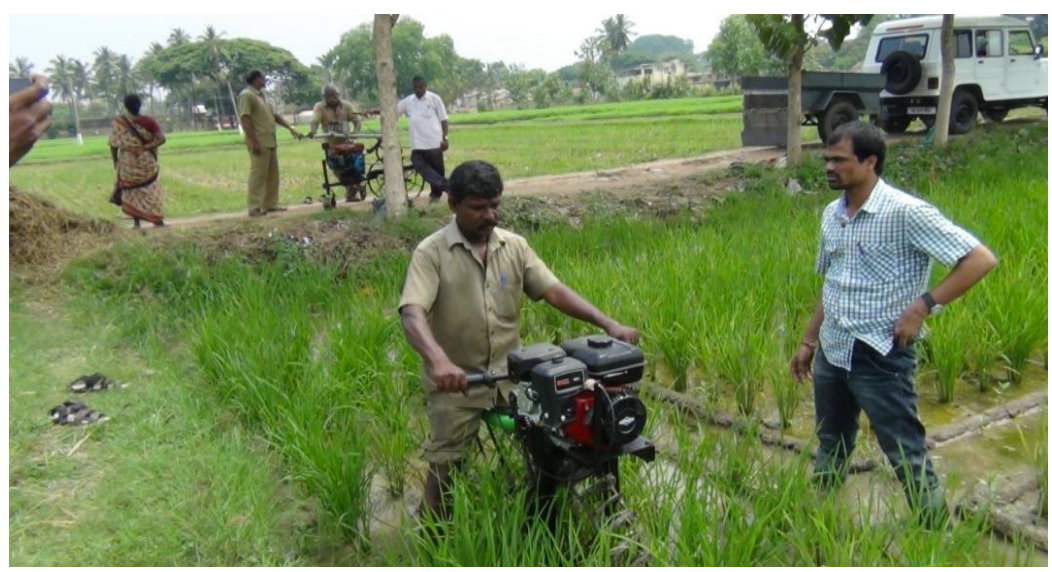

Fig.3 View of the field before weeding

Fig.4 View of the field after weeding

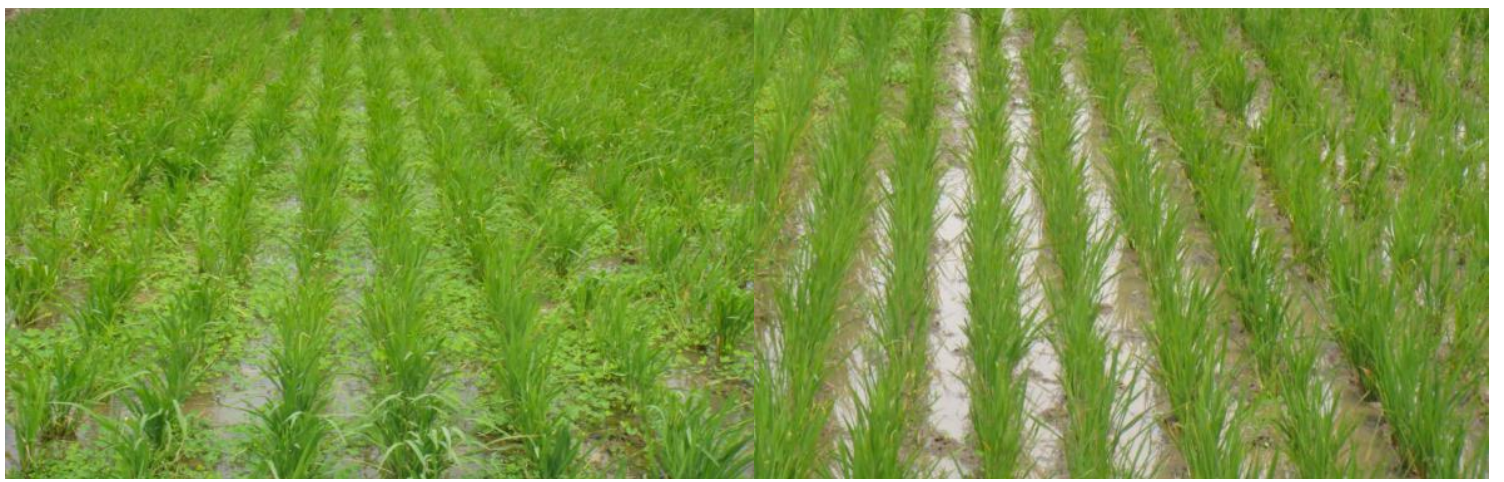

This observation was used for computation of fuel consumption in $\mathrm{L} / \mathrm{h}$.

\section{Results and Discussion}

Field evaluation of ride on type paddy weeder

The developed prototype self-propelled ride on type paddy weeder was evaluated in paddy field having cone index 0.14 to $2 \mathrm{~kg} \mathrm{~cm}^{-2}$.

\section{Wheel slippage}

Wheel slip for power weeder was measured by monitoring the number of revolutions of the wheel over a specified distance under load and zero load conditions. Number of revolutions of wheel in $10 \mathrm{~m}$ row under no load was 11 .
Number of revolutions of wheel in $10 \mathrm{~m}$ row under load was 13.

$$
S^{\prime}=\frac{n_{1}-n_{0}}{n_{0}} \times 100=15 \%
$$

The determined wheel slip of the prototype ride on type paddy weeder was $15 \%$.

\section{Effective field capacity}

The effective field capacity of the self-propelled ride on type weeder obtained from the experiments varied between $0.03 \mathrm{ha} / \mathrm{h}$ to 0.0306 $\mathrm{ha} / \mathrm{h}$ and the average effective field capacity of the weeder was $0.03004 \mathrm{ha} / \mathrm{h}$. The results are presented in Table 2 and Field view of paddy weeder shown in Figure 2. 


\section{Theoretical field capacity}

It is always greater than effective field capacity

Width of weeder is $0.15 \mathrm{~m}$ and speed of operation is $2.5 \mathrm{kmh}^{-1}$

T.F.C. $\left(\right.$ ha h $\left.^{-1}\right)=\frac{\mathrm{W}_{\mathrm{t}} \times \mathrm{S}}{10}=\frac{0.15 \times 2.5}{10}=0.0375 \mathrm{ha} \mathrm{h}^{-}$

\section{Field efficiency}

The field efficiency was calculated from theoretical and effective field capacity by using following formula.

Field efficiency $(\%)=\frac{\text { E.F.C. }}{\text { T.F.C. }} \times 100=\frac{0.03004}{0.0375}=$ $80.35 \%$

The field efficiency of the prototype weeder was $80.35 \%$ and effective field capacity and field efficiency of the weeder is given in Table 2 .

\section{Weeding efficiency}

The weeding efficiency of developed selfpropelled weeder was determined and presented in Table 3. Weeding operation of the experimental plot shown in Figure 3 and 4.

\section{Plant damage}

The plant damage was measured in paddy field and furnished in Table 4.

\section{Fuel consumption}

Fuel consumption of the weeder was calculated by "topping method". It was observed that the fuel consumption of the self-propelled ride on type paddy weeder varied between $0.557 \mathrm{~L} / \mathrm{h}$ to $0.635 \mathrm{~L} / \mathrm{h}$ and the average fuel consumption was $0.6 \mathrm{~L} / \mathrm{h}$ and given Table 5 .

In field evaluation the of developed ride on type paddy weeder the following evaluated parameters were wheel slip $15 \%$, effective field capacity 0.03004 hah-1, theoretical field capacity 0.0375 ha $\mathrm{h}-1$, field efficiency 80.35 $\%$, plant damage $3.33 \%$ and weeding efficiency $84.04 \%$. Fuel consumption of the weeder was 0.6 lit $^{-1}$ and cost of operation of developed weeder was Rs. $2741.11 \mathrm{ha}^{-1}$.From performance evaluation of ride on type paddy weeder found better than hand weeding and power operated paddy weeder in rice cultivation.

\section{References}

Barah, B.C. and Pandey, S., 2005, Rainfed rice production systems in Eastern India: An on farm diagnosis and policy alternatives. Indian Journal of Agricultural Economics, 60(1): 110-136.

Chaudhary V. P., S. K. Sharma., D. K. Pandey and B. Gangwar. 2006. Energy Assessment of Different Weed Management Practices for Rice-Wheat Cropping System in India.

Nag, P.K and P. Dutt. 1979. Effectiveness of some simple agricultural weeder with reference to physiological responses. Journal of Human Ergology, 8.1, 13:21.

Pathak, M.D., Ou, S.H. and S.K. de Datta.1976.Pesticides and Human Welfare. (Eds D. LG unn and J.G.R. Stephens). Oxford University Press.

Remesan, R., M.S. Roopesh, N. Remya and P.S. Preman. "Wet Land Paddy Weeding - A Comprehensive Comparative Study from South India". Agricultural Engineering International: the CIGR E journal. Manuscript PM 07 011. Vol. IX. December, 2007.

\section{How to cite this article:}

Basavaraj, A. Surendrakumar, Vinayak and Vivek, P. 2018. Performance Evaluation of Prototype Ride on Type Paddy Weeder. Int.J.Curr.Microbiol.App.Sci. 7(05): 3694-3700. doi: https://doi.org/10.20546/ijcmas.2018.705.427 